\title{
Contribution to the investigation of the $\mathrm{Y}-\mathrm{Cu}-\mathrm{Sn}$ ternary system
}

\author{
Lyubov ROMAKA ${ }^{1}$, Ivanna ROMANIV ${ }^{1}$, Yuriy STADNYK ${ }^{1}$, Vitaliy V. ROMAKA ${ }^{2}$, Roman SERKIZ ${ }^{1}$, \\ Roman GLADYSHEVSKII $^{1}$ \\ ${ }^{1}$ Department of Inorganic Chemistry, Ivan Franko Lviv National University, \\ Kyryla i Mefodiya St. 6, 79005 Lviv, Ukraine \\ ${ }^{2}$ Department of Materials Engineering and Applied Physics, Lviv Polytechnic National University, \\ Ustyyanovycha St. 5, 79013 Lviv, Ukraine \\ * Corresponding author. E-mail: romakal@franko.lviv.ua
}

Dedicated to Evgen I. Gladyshevskii (1924-2012)

Received April 10, 2014; accepted June 26, 2014; available on-line November 10, 2014

The isothermal section of the phase diagram of the $\mathrm{Y}-\mathrm{Cu}-\mathrm{Sn}$ ternary system was constructed at $673 \mathrm{~K}$ in the whole concentration range, using X-ray diffraction and EPM analyses. The interaction between the elements results in the formation of five ternary compounds at the investigated temperature: YCuSn (NdPtSb-type structure), $\quad \mathrm{Y}_{3} \mathrm{Cu}_{4} \mathrm{Sn}_{4} \quad\left(\mathrm{Gd}_{3} \mathrm{Cu}_{4} \mathrm{Ge}_{4}\right.$-type $), \quad \mathrm{YCu}_{5} \mathrm{Sn} \quad\left(\mathrm{CeCu}_{6}\right.$-type $), \quad \mathrm{Y}_{1.9} \mathrm{Cu}_{9.2} \mathrm{Sn}_{2.8} \quad\left(\mathrm{CeNi}_{5} \mathrm{Sn}\right.$-type), and $\mathrm{YCu}_{4.65} \mathrm{Sn}_{0.35}\left(\mathrm{MgCu}_{4} \mathrm{Sn}\right.$-type).

\section{Intermetallics / Rare-earth metal system / Phase diagram / X-ray diffraction}

\section{Introduction}

The study of phase diagrams of metallic systems is an important step to determine the relations of the components in equilibrium with neighboring phases, the homogeneity ranges and structural data of intermediate phases. The first results of a partial investigation of the $\mathrm{Y}-\mathrm{Cu}-\mathrm{Sn}$ ternary system (40 at.\% $\mathrm{Y}$ or less) at $770 \mathrm{~K}$ were presented in [1]. Three ternary compounds with unknown structure were reported in the investigated part: $\mathrm{Y}_{3} \mathrm{Cu}_{4} \mathrm{Sn}_{3}$ ( $\beta$-phase), $\mathrm{Y}_{8} \mathrm{Cu}_{7} \mathrm{Sn}_{5}$ ( $\theta$-phase), and $\mathrm{Y}_{19} \mathrm{Cu}_{66} \mathrm{Sn}_{15}$ ( $\gamma$-phase). Investigations of $\mathrm{Y}-\mathrm{Cu}-\mathrm{Sn}$ alloys by other authors indicated the existence of several $\mathrm{Y}-\mathrm{Cu}-\mathrm{Sn}$ stannides: YCuSn $\left(\mathrm{CaIn}_{2}\right.$-type structure [2], NdPtSb-type [3]), $\mathrm{Y}_{3} \mathrm{Cu}_{4} \mathrm{Sn}_{4} \quad\left(\mathrm{Gd}_{3} \mathrm{Cu}_{4} \mathrm{Ge}_{4}\right.$-type $)$ [4], $\mathrm{YCu}_{5} \mathrm{Sn}\left(\mathrm{CeCu}_{6^{-}}\right.$ type) [5], $\mathrm{YCu}_{2} \mathrm{Sn}_{2} \quad\left(\mathrm{CaBe}_{2} \mathrm{Ge}_{2}\right.$-type $) \quad[6], \quad$ and $\mathrm{Y}_{1.9} \mathrm{Cu}_{9.2} \mathrm{Sn}_{2.8}\left(\mathrm{CeNi}_{5} \mathrm{Sn}\right.$-type) [7]. Analysis of earlier studied $R-\mathrm{Cu}-\mathrm{Sn}$ ternary systems with rare earths of the yttrium group $(R=\mathrm{Gd}, \mathrm{Dy}, \mathrm{Er}, \mathrm{Lu})$ [8-11] showed a decreasing number of compounds, down to three for the $\mathrm{Lu}-\mathrm{Cu}-\mathrm{Sn}$ system. The $\mathrm{Yb}-\mathrm{Cu}-\mathrm{Sn}$ system constitutes an exception with ten intermediate phases found at $673 \mathrm{~K} \mathrm{[12]}$. Investigations of the $\mathrm{Gd}-\mathrm{Cu}-\mathrm{Sn}$ and $\mathrm{Dy}-\mathrm{Cu}-\mathrm{Sn}$ systems at 670 and $770 \mathrm{~K}$ indicated an important influence of the temperature on the formation of ternary phases at high Sn content $[8,13]$.

Considering the relatively limited data available on the phase diagram, as well as the composition and structure of some of the ternary compounds in the $\mathrm{Y}-\mathrm{Cu}-\mathrm{Sn}$ system, we decided to fill in this gap. In the present paper the results of $\mathrm{X}$-ray and EPM analyses of the phase equilibria in the $\mathrm{Y}-\mathrm{Cu}-\mathrm{Sn}$ system at $673 \mathrm{~K}$ are reported.

\section{Experimental details}

The samples were prepared by arc melting of the constituent elements (yttrium, with a purity of 99.9 wt.\%; copper, 99.99 wt.\%; tin, 99.999 wt.\%) under high-purity Ti-gettered argon atmosphere on a water-cooled copper crucible. The total weight losses with respect to the initial mass were lower than $1 \mathrm{wt} . \%$. Pieces of the as-cast buttons were annealed for one month at $673 \mathrm{~K}$ in evacuated silica tubes, and then water-quenched. For additional studies, some samples were annealed at $773 \mathrm{~K}$ under similar conditions. Phase analysis of the samples was performed using X-ray powder diffraction (DRON4.0, Fe $K \alpha$ radiation). The observed diffraction intensities were compared with reference powder patterns of the binary and known ternary phases. The compositions of the samples were examined by Scanning Electron Microscopy (SEM), using a REMMA-102-02 scanning microscope. Quantitative electron probe microanalysis (EPMA) of the phases was carried out with an energy-dispersive X-ray analyzer, using the pure elements as standards (the acceleration voltage was $20 \mathrm{kV} ; K$ - and $L$-lines were 
used). Calculations of the crystallographic parameters and theoretical diffraction patterns were performed with the CSD program package [14] and Rietveld refinements with the WinPLOTR program package [15].

\section{Results and discussion}

The binary systems

Data for the $\mathrm{Y}-\mathrm{Sn}$ binary system were taken from $[16,17]$, data for the $\mathrm{Y}-\mathrm{Cu}$ and $\mathrm{Cu}-\mathrm{Sn}$ systems were found in [17-20].

Phase analysis of samples in the $\mathrm{Y}-\mathrm{Cu}$ binary system confirmed formation of $\mathrm{YCu}_{5}\left(\mathrm{CaCu}_{5}\right.$-type structure $), \mathrm{Y}_{0.8} \mathrm{Cu}_{5.4}\left(\mathrm{~Tb}_{0.78} \mathrm{Cu}_{5.44}\right.$-type $), \mathrm{YCu}_{2}\left(\mathrm{KHg}_{2^{-}}\right.$ type), and $\mathrm{YCu}$ (CsCl-type).

In the $\mathrm{Y}-\mathrm{Sn}$ system the presence of $\mathrm{Y}_{5} \mathrm{Sn}_{3}$ $\left(\mathrm{Mn}_{5} \mathrm{Si}_{3}\right.$-type structure), $\mathrm{Y}_{5} \mathrm{Sn}_{4} \quad\left(\mathrm{Sm}_{5} \mathrm{Ge}_{4}\right.$-type), $\mathrm{Y}_{11} \mathrm{Sn}_{10}\left(\mathrm{Ho}_{11} \mathrm{Ge}_{10}\right.$-type), $\mathrm{YSn}_{2}\left(\mathrm{ZrSi}_{2}\right.$-type), and $\mathrm{YSn}_{3}$ $\left(\mathrm{GdSn}_{2.75}\right.$-type) at $673 \mathrm{~K}$ was confirmed. The $\mathrm{Y}_{2} \mathrm{Sn}_{5}$ compound with $\mathrm{Er}_{2} \mathrm{Ge}_{5}$-type structure ( $a=0.4301(3)$, $b=0.4407(4), c=1.9071(2) \mathrm{nm})$, existing at $673 \mathrm{~K}$ according to [16], was also observed in our study.

The presence of the $\mathrm{Cu}_{3} \mathrm{Sn}\left(\mathrm{Cu}_{3} \mathrm{Sn}\right.$-type $), \mathrm{Cu}_{41} \mathrm{Sn}_{11}$ $\left(\mathrm{Cu}_{41} \mathrm{Sn}_{11}\right.$-type $)$ and $\mathrm{Cu}_{6} \mathrm{Sn}_{5} \quad\left(\mathrm{Cu}_{6} \mathrm{Sn}_{5}\right.$-type $)$ binary compounds in the $\mathrm{Cu}-\mathrm{Sn}$ system was confirmed.

\section{Isothermal section at $673 \mathrm{~K}$}

The phase equilibria in the $\mathrm{Y}-\mathrm{Cu}-\mathrm{Sn}$ system were investigated at $673 \mathrm{~K}$, based on $\mathrm{X}$-ray diffraction and metallographic analysis of 14 binary and 32 ternary alloys. The isothermal section of the phase diagram at $673 \mathrm{~K}$ is presented in Fig. 1. The phase compositions of selected samples are listed in Table 1, and microphotographs of some alloys are shown in Fig. 2. The phase relations in the $\mathrm{Y}-\mathrm{Cu}-\mathrm{Sn}$ system under the conditions applied here are characterized by the formation of five ternary compounds, $\mathrm{YCuSn}$, $\mathrm{Y}_{3} \mathrm{Cu}_{4} \mathrm{Sn}_{4}, \mathrm{YCu}_{5} \mathrm{Sn}, \mathrm{Y}_{1.9} \mathrm{Cu}_{9.2} \mathrm{Sn}_{2.8}$, and $\mathrm{YCu}_{4.65} \mathrm{Sn}_{0.35}$, the crystallographic characteristics of which are listed in Table 2. All the ternary compounds in the $\mathrm{Y}-\mathrm{Cu}-\mathrm{Sn}$ ternary system are characterized by narrow homogeneity ranges at the investigated temperature. No significant solubility of the third component was observed for the binary phases.

The $\mathrm{YCu}_{2} \mathrm{Sn}_{2}$ compound with $\mathrm{CaBe}_{2} \mathrm{Ge}_{2}$-type structure, reported in [6], was not observed during our study of the $\mathrm{Y}-\mathrm{Cu}-\mathrm{Sn}$ system. Powder XRD analysis of samples near this composition revealed that they belong to a three-phase field involving mainly the ternary phase $\mathrm{Y}_{3} \mathrm{Cu}_{4} \mathrm{Sn}_{4}$, binary $\mathrm{Cu}_{6} \mathrm{Sn}_{5}$ and $\mathrm{Sn}$. The formation of the $\mathrm{YCu}_{2} \mathrm{Sn}_{2}$ compound can be connected with the different temperature of annealing used by the authors of [6] (annealing at 873-1073 K).

The $\mathrm{YCu}_{5} \mathrm{Sn}$ compound was observed at the stoichiometry 1:5:1, confirmed by EDX analysis $\left(\mathrm{Y}_{14.2} \mathrm{Cu}_{71.9} \mathrm{Sn}_{13.9}\right)$. At higher $\mathrm{Sn}$ content, the existence of the $\mathrm{Y}_{1.9} \mathrm{Cu}_{9.2} \mathrm{Sn}_{2.8}$ compound with a hexagonal structure related to the $\mathrm{CeNi}_{5} \mathrm{Sn}$ type (a partly disordered substitution variant) [7] was confirmed.

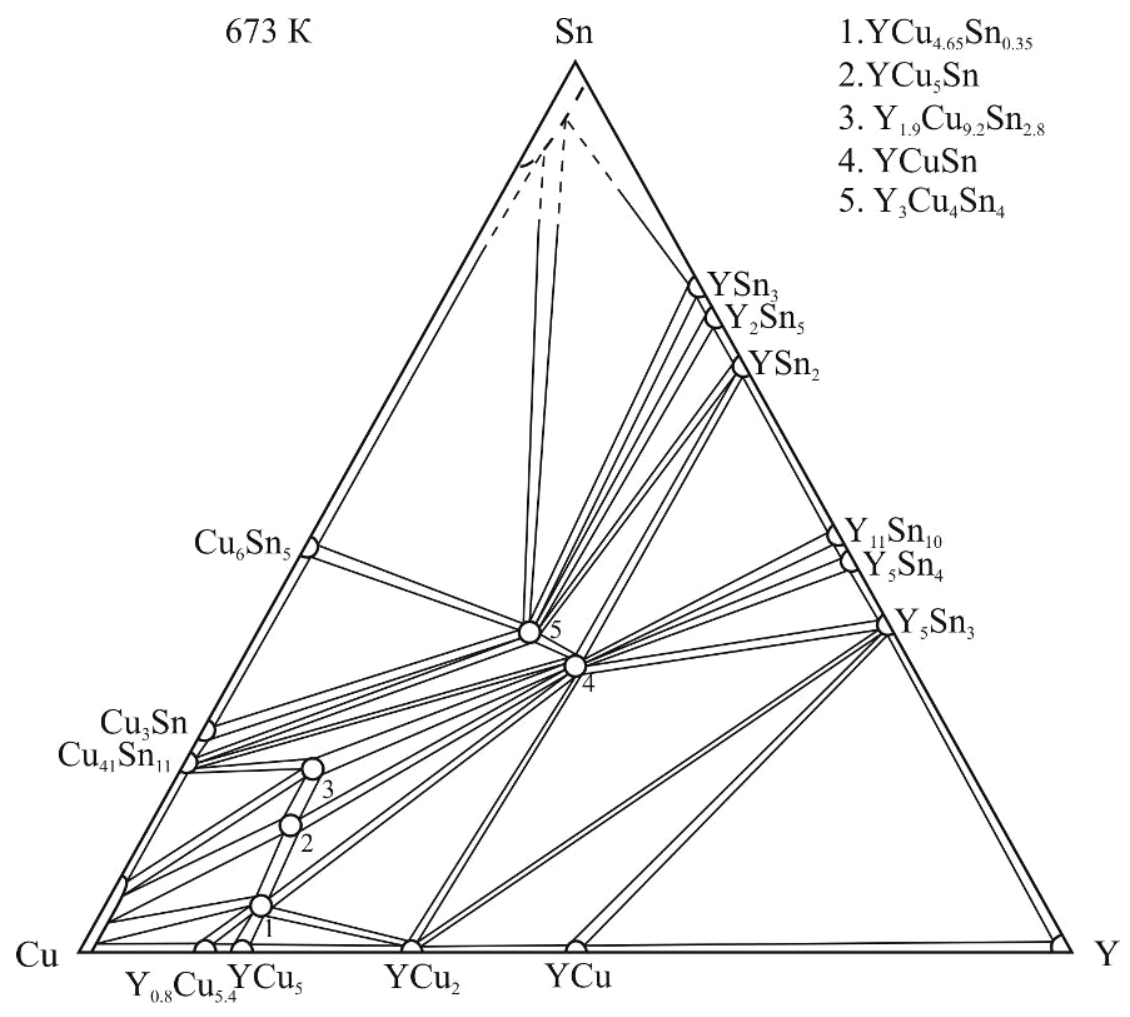

Fig. 1 Isothermal section of the phase diagram of the $\mathrm{Y}-\mathrm{Cu}-\mathrm{Sn}$ system at $673 \mathrm{~K}$. 
Table 1 Phase compositions of selected $\mathrm{Y}-\mathrm{Cu}-\mathrm{Sn}$ alloys (annealed at $673 \mathrm{~K}$ if not indicated otherwise).

\begin{tabular}{|c|c|c|c|c|c|c|}
\hline \multirow[t]{2}{*}{ No. } & \multicolumn{3}{|c|}{$\begin{array}{c}\text { Nominal alloy } \\
\text { composition (at.\%) }\end{array}$} & \multicolumn{3}{|c|}{ Phases } \\
\hline & $\mathrm{Y}$ & $\mathrm{Cu}$ & $\mathrm{Sn}$ & $1^{\text {st }}$ phase & $2^{\text {nd }}$ phase & $3^{\text {rd }}$ phase \\
\hline 1 & 20 & 73 & 7 & $\begin{array}{l}\mathrm{YCu}_{4.65} \mathrm{Sn}_{0.35} \\
a=0.7088(2) \mathrm{nm}\end{array}$ & $\begin{array}{l}\mathrm{YCuSn} \\
a=0.4506(2) \mathrm{nm} \\
c=0.7275(3) \mathrm{nm}\end{array}$ & $\begin{array}{l}\mathrm{YCu}_{2} \\
a=0.4299(4) \mathrm{nm} \\
b=0.6788(3) \mathrm{nm} \\
c=0.7299(8) \mathrm{nm}\end{array}$ \\
\hline 2 & 17 & 70 & 13 & $\begin{array}{l}\mathrm{YCu}_{5} \mathrm{Sn} \\
a=0.8206(5) \mathrm{nm} \\
b=0.9979(3) \mathrm{nm} \\
c=1.0497(4) \mathrm{nm}\end{array}$ & $\begin{array}{l}\text { YCuSn } \\
a=0.4505(3) \mathrm{nm} \\
c=0.7274(5) \mathrm{nm}\end{array}$ & $\begin{array}{l}\mathrm{YCu}_{4.65} \mathrm{Sn}_{0.35} \\
a=0.7081(3) \mathrm{nm}\end{array}$ \\
\hline 3 & 13 & 72 & 15 & $\begin{array}{l}\mathrm{YCu}_{5} \mathrm{Sn} \\
a=0.8205(4) \mathrm{nm} \\
b=0.9980(4) \mathrm{nm} \\
c=1.0498(6) \mathrm{nm}\end{array}$ & $\begin{array}{l}\mathrm{Y}_{1.9} \mathrm{Cu}_{9.2} \mathrm{Sn}_{2.8} \\
a=0.5036(4) \mathrm{nm} \\
c=2.0441(6) \mathrm{nm}\end{array}$ & $\begin{array}{l}(\mathrm{Cu}) \\
a=0.3621(2) \mathrm{nm}\end{array}$ \\
\hline 4 & 19 & 66 & 15 & $\begin{array}{l}\mathrm{Y}_{1.9} \mathrm{Cu}_{9.2} \mathrm{Sn}_{2.8} \\
a=0.5035(2) \mathrm{nm} \\
c=2.0444(4) \mathrm{nm}\end{array}$ & $\begin{array}{l}\mathrm{YCu}_{5} \mathrm{Sn} \\
a=0.8209(4) \mathrm{nm} \\
b=0.4973(3) \mathrm{nm} \\
c=1.0571(5) \mathrm{nm}\end{array}$ & $\begin{array}{l}\text { YCuSn } \\
a=0.4511(3) \mathrm{nm} \\
c=0.7277(4) \mathrm{nm}\end{array}$ \\
\hline $\begin{array}{c}4 \\
(773 \mathrm{~K})\end{array}$ & 19 & 66 & 15 & $\begin{array}{l}\mathrm{Y}_{1.9} \mathrm{Cu}_{9.2} \mathrm{Sn}_{2.8} \\
a=0.5034(3) \mathrm{nm} \\
c=2.0443(6) \mathrm{nm}\end{array}$ & $\begin{array}{l}\mathrm{YCu}_{5} \mathrm{Sn} \\
a=0.4423(2) \mathrm{nm} \\
b=0.6912(3) \mathrm{nm} \\
c=1.4622(8) \mathrm{nm}\end{array}$ & $\begin{array}{l}\text { YCuSn } \\
a=0.4507(2) \mathrm{nm} \\
c=0.7274(5) \mathrm{nm}\end{array}$ \\
\hline 5 & 50 & 30 & 20 & $\begin{array}{l}\mathrm{Y}_{5} \mathrm{Sn}_{3} \\
a=0.8877(5) \mathrm{nm} \\
c=0.6521(4) \mathrm{nm}\end{array}$ & $\begin{array}{l}\mathrm{YCu}_{2} \\
a=0.4300(3) \mathrm{nm} \\
b=0.6789(4) \mathrm{nm} \\
c=0.7289(8) \mathrm{nm}\end{array}$ & \\
\hline 6 & 40 & 35 & 25 & $\begin{array}{l}\text { YCuSn } \\
a=0.4508(3) \mathrm{nm} \\
c=0.7276(4) \mathrm{nm}\end{array}$ & $\begin{array}{l}\mathrm{Y}_{5} \mathrm{Sn}_{3} \\
a=0.8881(4) \mathrm{nm} \\
c=0.6519(5) \mathrm{nm}\end{array}$ & $\begin{array}{l}\mathrm{YCu}_{2} \\
\text { (traces) }\end{array}$ \\
\hline $\begin{array}{c}6 \\
(773 \mathrm{~K})\end{array}$ & 40 & 35 & 25 & $\begin{array}{l}\text { YCuSn } \\
a=0.4508(4) \mathrm{nm} \\
c=0.7275(5) \mathrm{nm}\end{array}$ & $\begin{array}{l}\mathrm{Y}_{5} \mathrm{Sn}_{3} \\
a=0.8879(4) \mathrm{nm} \\
c=0.6525(6) \mathrm{nm}\end{array}$ & $\begin{array}{l}\mathrm{YCu}_{2} \\
\text { (traces) }\end{array}$ \\
\hline 7 & 30 & 40 & 30 & $\begin{array}{l}\text { YCuSn } \\
a=0.4509(2) \mathrm{nm} \\
c=0.7278(4) \mathrm{nm}\end{array}$ & $\begin{array}{l}\mathrm{Y}_{1.9} \mathrm{Cu}_{9.2} \mathrm{Sn}_{2.8} \\
a=0.5036(2) \mathrm{nm} \\
c=2.0441(5) \mathrm{nm}\end{array}$ & $\begin{array}{l}\mathrm{Cu}_{41} \mathrm{Sn}_{11} \\
\text { (not determined) }\end{array}$ \\
\hline $\begin{array}{c}7 \\
(773 \mathrm{~K})\end{array}$ & 30 & 40 & 30 & $\begin{array}{l}\text { YCuSn } \\
a=0.4510(3) \mathrm{nm} \\
c=0.7278(5) \mathrm{nm}\end{array}$ & $\begin{array}{l}\mathrm{Y}_{1.9} \mathrm{Cu}_{9.2} \mathrm{Sn}_{2.8} \\
a=0.5033(3) \mathrm{nm} \\
c=2.0445(7) \mathrm{nm}\end{array}$ & $\begin{array}{l}\mathrm{Cu}_{41} \mathrm{Sn}_{11} \\
\text { (traces) }\end{array}$ \\
\hline 8 & 15 & 55 & 30 & $\begin{array}{l}\mathrm{Y}_{3} \mathrm{Cu}_{4} \mathrm{Sn}_{4} \\
a=0.4421(3) \mathrm{nm} \\
b=0.6912(4) \mathrm{nm} \\
c=1.4618(8) \mathrm{nm}\end{array}$ & $\begin{array}{l}\mathrm{Cu}_{3} \mathrm{Sn} \\
a=0.4319(3) \mathrm{nm} \\
b=0.5488(4) \mathrm{nm} \\
c=0.4737(4) \mathrm{nm}\end{array}$ & \\
\hline 9 & 55 & 10 & 35 & $\begin{array}{l}\mathrm{Y}_{5} \mathrm{Sn}_{3} \\
a=0.8878(1) \mathrm{nm} \\
c=0.6521(1) \mathrm{nm}\end{array}$ & $\begin{array}{l}\mathrm{YCuSn} \\
a=0.4507(4) \mathrm{nm} \\
c=0.7279(5) \mathrm{nm}\end{array}$ & \\
\hline 10 & 20 & 40 & 40 & $\begin{array}{l}\mathrm{Y}_{3} \mathrm{Cu}_{4} \mathrm{Sn}_{4} \\
a=0.4423(2) \mathrm{nm} \\
b=0.6912(3) \mathrm{nm} \\
c=1.4622(8) \mathrm{nm}\end{array}$ & $\begin{array}{l}\mathrm{Cu}_{6} \mathrm{Sn}_{5} \\
a=1.1015(6) \mathrm{nm} \\
b=0.7273(4) \mathrm{nm} \\
c=0.9817(5) \mathrm{nm} \\
\beta=98.79^{\circ}\end{array}$ & $\begin{array}{l}(\mathrm{Sn}) \\
a=0.5809(3) \mathrm{nm} \\
c=0.3179(3) \mathrm{nm}\end{array}$ \\
\hline 11 & 40 & 20 & 40 & $\begin{array}{l}\text { YCuSn } \\
a=0.4509(4) \mathrm{nm} \\
c=0.7278(4) \mathrm{nm}\end{array}$ & $\begin{array}{l}\mathrm{YSn}_{2} \\
a=0.4393(3) \mathrm{nm} \\
b=1.6322(5) \mathrm{nm} \\
c=0.4301(4) \mathrm{nm}\end{array}$ & $\begin{array}{l}\mathrm{Y}_{11} \mathrm{Sn}_{10} \\
a=1.1509(5) \mathrm{nm} \\
c=1.6888(5) \mathrm{nm}\end{array}$ \\
\hline
\end{tabular}


Table 1 Phase compositions of selected $\mathrm{Y}-\mathrm{Cu}-\mathrm{Sn}$ alloys (annealed at $673 \mathrm{~K}$ if not indicated otherwise) (continued).

\begin{tabular}{|c|c|c|c|c|c|c|}
\hline \multirow[t]{2}{*}{ No. } & \multicolumn{3}{|c|}{$\begin{array}{c}\text { Nominal alloy } \\
\text { composition (at.\%) }\end{array}$} & \multicolumn{3}{|c|}{ Phases } \\
\hline & $\mathrm{Y}$ & $\mathrm{Cu}$ & $\mathrm{Sn}$ & $1^{\text {st }}$ phase & $2^{\text {nd }}$ phase & $3^{\text {rd }}$ phase \\
\hline 12 & 15 & 35 & 50 & $\begin{array}{l}\mathrm{Y}_{3} \mathrm{Cu}_{4} \mathrm{Sn}_{4} \\
a=0.4421(2) \mathrm{nm} \\
b=0.6909(4) \mathrm{nm} \\
c=1.4619(8) \mathrm{nm}\end{array}$ & $\begin{array}{l}\mathrm{Cu}_{6} \mathrm{Sn}_{5} \\
a=1.1014(6) \mathrm{nm} \\
b=0.7272(4) \mathrm{nm} \\
c=0.9817(6) \mathrm{nm} \\
\beta=98.78^{\circ}\end{array}$ & $\begin{array}{l}(\mathrm{Sn}) \\
a=0.5807(2) \mathrm{nm} \\
c=0.3177(3) \mathrm{nm}\end{array}$ \\
\hline 13 & 20 & 25 & 55 & $\begin{array}{l}\mathrm{Y}_{3} \mathrm{Cu}_{4} \mathrm{Sn}_{4} \\
a=0.4425(3) \mathrm{nm} \\
b=0.6909(5) \mathrm{nm} \\
c=1.4620(8) \mathrm{nm}\end{array}$ & $\begin{array}{l}(\mathrm{Sn}) \\
a=0.5808(4) \mathrm{nm} \\
c=0.3177(5) \mathrm{nm}\end{array}$ & \\
\hline 14 & 25 & 15 & 60 & $\begin{array}{l}\mathrm{Y}_{2} \mathrm{Sn}_{5} \\
a=0.4321(4) \mathrm{nm} \\
b=0.4407(5) \mathrm{nm} \\
c=1.9088(8) \mathrm{nm}\end{array}$ & $\begin{array}{l}\mathrm{Y}_{3} \mathrm{Cu}_{4} \mathrm{Sn}_{4} \\
a=0.4423(3) \mathrm{nm} \\
b=0.6910(4) \mathrm{nm} \\
c=1.4619(8) \mathrm{nm}\end{array}$ & $\begin{array}{l}\mathrm{YSn}_{3} \\
a=0.4340(3) \mathrm{nm} \\
b=0.4383(6) \mathrm{nm} \\
c=1.1929(8) \mathrm{nm}\end{array}$ \\
\hline 15 & 30 & 5 & 65 & $\begin{array}{l}\mathrm{Y}_{3} \mathrm{Cu}_{4} \mathrm{Sn}_{4} \\
a=0.4423(3) \mathrm{nm} \\
b=0.6909(3) \mathrm{nm} \\
c=1.4618(7) \mathrm{nm}\end{array}$ & $\begin{array}{l}\mathrm{YSn}_{2} \\
a=0.4392(4) \mathrm{nm} \\
b=1.6329(6) \mathrm{nm} \\
c=0.4301(3) \mathrm{nm}\end{array}$ & $\begin{array}{l}\mathrm{Y}_{2} \mathrm{Sn}_{5} \\
a=0.4319(3) \mathrm{nm} \\
b=0.4401(5) \mathrm{nm} \\
c=1.9085(7) \mathrm{nm}\end{array}$ \\
\hline
\end{tabular}

Table 2 Crystallographic data for the ternary compounds in the $\mathrm{Y}-\mathrm{Cu}-\mathrm{Sn}$ system.

\begin{tabular}{|c|c|c|c|c|c|c|}
\hline \multirow{2}{*}{ No. ${ }^{a}$} & \multirow{2}{*}{ Compound } & \multirow{2}{*}{ Structure type } & \multirow{2}{*}{ Space group } & \multicolumn{3}{|c|}{ Unit-cell parameters, $\mathrm{nm}$} \\
\hline & & & & $a$ & $b$ & $c$ \\
\hline 1 & $\mathrm{YCu}_{4.65} \mathrm{Sn}_{0.35}$ & $\mathrm{MgCu}_{4} \mathrm{Sn}$ & $F-43 m$ & $0.7086(1)$ & - & - \\
\hline 2 & $\mathrm{YCu}_{5} \mathrm{Sn}$ & $\mathrm{CeCu}_{6}$ & Pnma & $0.8206(5)$ & $0.4979(3)$ & $1.0497(4)$ \\
\hline 3 & $\mathrm{Y}_{1.9} \mathrm{Cu}_{9.2} \mathrm{Sn}_{2.8}$ & $\mathrm{CeNi}_{5} \mathrm{Sn}$ & $P 6_{3} / m m c$ & $0.50348(2)$ & - & $2.0444(1)$ \\
\hline 4 & YCuSn & $\mathrm{NdPtSb}$ & $P 6_{3} m c$ & $0.4504(1)$ & - & $0.7270(4)$ \\
\hline 5 & $\mathrm{Y}_{3} \mathrm{Cu}_{4} \mathrm{Sn}_{4}$ & $\mathrm{Gd}_{3} \mathrm{Cu}_{4} \mathrm{Ge}_{4}$ & Immm & $1.4622(8)$ & $0.6912(3)$ & $0.4423(2)$ \\
\hline
\end{tabular}

${ }^{\mathrm{a}}$ The compound numbers correspond to the labels in the phase diagram (Fig. 1).

Other phases reported in the literature

"Y $\mathbf{C u}_{7} \mathrm{Sn}_{5}$ "

To check the existence of the " $\mathrm{Y}_{8} \mathrm{Cu}_{7} \mathrm{Sn}_{5}$ " compound, identified as one of the three ternary phases observed in the Y-poor part of the $\mathrm{Y}-\mathrm{Cu}-\mathrm{Sn}$ system at $773 \mathrm{~K}$ ( $\theta$-phase) [1], samples near the composition $\mathrm{Y}_{40} \mathrm{Cu}_{35} \mathrm{Sn}_{25}$ were prepared and annealed at 673 or $773 \mathrm{~K}$. Detailed phase analysis of the samples annealed at either temperature revealed that they belong to a three-phase field involving as main phase ternary $\mathrm{YCuSn}$ with NdPtSb-type structure, in equilibrium with the binary phases $\mathrm{Y}_{5} \mathrm{Sn}_{3}$ and $\mathrm{YCu}_{2}$. The strongest reflections in the diffraction data, indexed on an orthorhombic unit cell with $a=0.9702$, $b=0.7285, c=0.6545 \mathrm{~nm}$ in [1], can be attributed to $\mathrm{YCuSn}$, and it is possible that the $\mathrm{Sn}$ content was underestimated when a tentative chemical formula was assigned to the Y-richest ternary compound in the phase diagram. It may be noted that most of the $R-\mathrm{Cu}-\mathrm{Sn}$ systems have been investigated [8-13,21-24], but none of the studies has shown any indication of a ternary phase at a composition close to " $R_{8} \mathrm{Cu}_{7} \mathrm{Sn}_{5}$ ". The powder pattern of the " $\mathrm{Y}_{8} \mathrm{Cu}_{7} \mathrm{Sn}_{5}$ " phase reported in [1] was successfully indexed on the basis of a hexagonal lattice (space group $\mathrm{P6}_{3} \mathrm{mc}$ ) with cell parameters $a=0.45035(4), c=0.7284(1) \mathrm{nm}$, corresponding to the $\mathrm{YCuSn}$ compound. The refined lattice parameters are in good agreement with those reported previously [2,3], and with those found during our investigation. The presence of a small amount of binary $\mathrm{Y}_{5} \mathrm{Sn}_{3}$ was also identified $(a=0.8863(8)$, $c=0.6592(6) \mathrm{nm})$.

\section{"Y $\mathbf{Y}_{3} \mathrm{Cu}_{4} \mathrm{Sn}_{3}$ "}

Two pieces of an $\mathrm{Y}_{30} \mathrm{Cu}_{40} \mathrm{Sn}_{30}$ sample were annealed at 673 and $773 \mathrm{~K}$, respectively. X-ray analysis of both samples showed the presence of $\mathrm{YCuSn}$ (NdPtSbtype), and minor amounts of $\mathrm{Y}_{1.9} \mathrm{Cu}_{9.2} \mathrm{Sn}_{2.8}$ (structure related to the $\mathrm{CeNi}_{5} \mathrm{Sn}$ type) and binary $\mathrm{Cu}_{41} \mathrm{Sn}_{11}$. This means that the composition " $\mathrm{Y}_{3} \mathrm{Cu}_{4} \mathrm{Sn}_{3}$ ", assigned to the ternary phase ( $\beta$-phase) identified in [1], corresponds to a three-phase field both at 673 and $773 \mathrm{~K}$. A rough comparison of the two phase diagrams (theirs at $773 \mathrm{~K}$ and ours at $673 \mathrm{~K}$ ) seems to indicate that the Sn-content may have been underestimated also here and the ternary compound referred to as " $\mathrm{Y}_{3} \mathrm{Cu}_{4} \mathrm{Sn}_{3}$ " in [1] may have been $\mathrm{Y}_{3} \mathrm{Cu}_{4} \mathrm{Sn}_{4}$. 


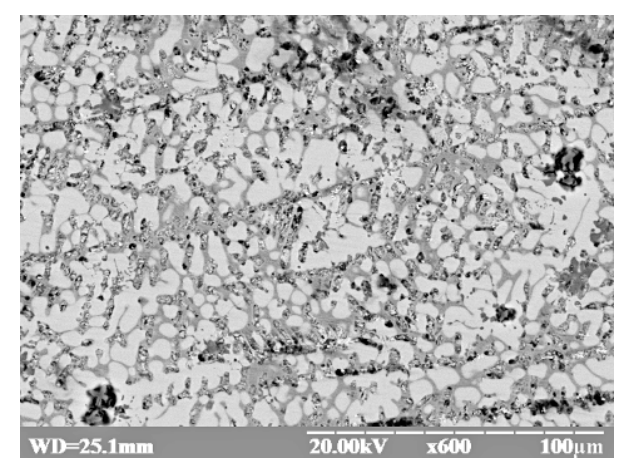

a
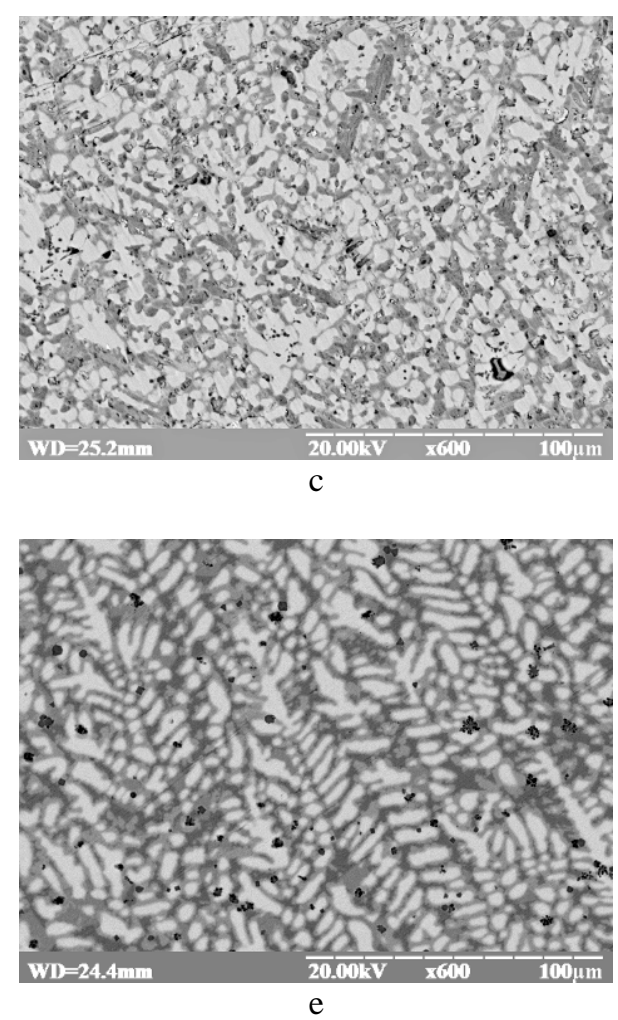

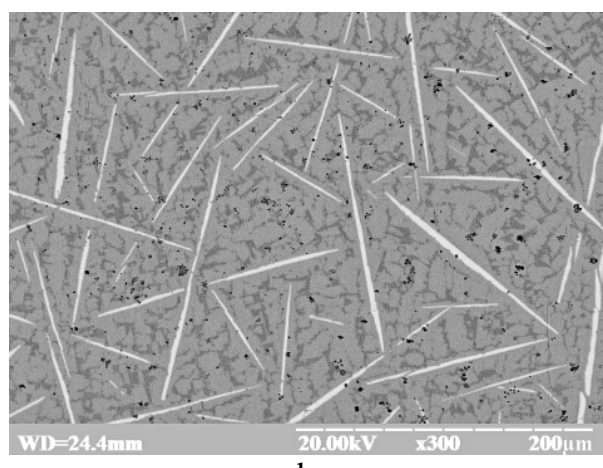

$\mathrm{b}$

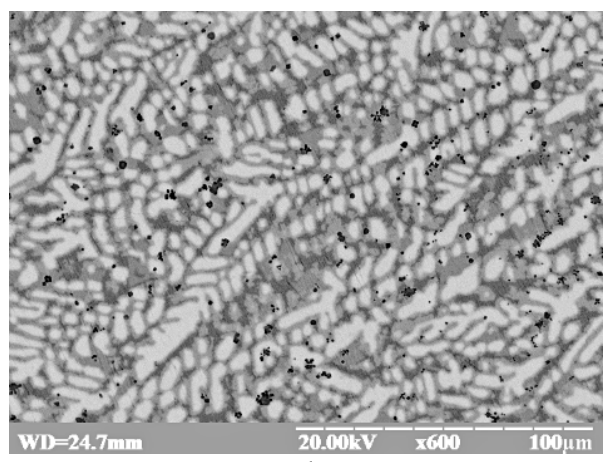

d

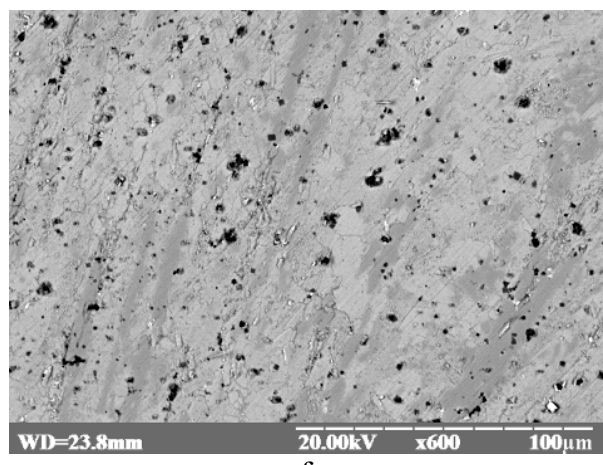

f

Fig. 2 Electron micrographs of the following alloys (numbering according to Table 1): (a) 7. $\mathrm{Y}_{30} \mathrm{Cu}_{40} \mathrm{Sn}_{30}-$ YCuSn (light gray phase); $\mathrm{Cu}_{41} \mathrm{Sn}_{11}$ (gray phase); $\mathrm{Y}_{1.9} \mathrm{Cu}_{9.2} \mathrm{Sn}_{2.8}$ (dark gray phase); (b) 1. $\mathrm{Y}_{17} \mathrm{Cu}_{76} \mathrm{Sn}_{7}-$ $\mathrm{YCu}_{4.65} \mathrm{Sn}_{0.35}$ (gray phase); $\mathrm{YCu}_{2}$ (dark gray phase); $\mathrm{YCuSn}$ (white phase); (c) $6 . \mathrm{Y}_{40} \mathrm{Cu}_{35} \mathrm{Sn}_{25}-\mathrm{YCuSn}$ (light gray phase); $\mathrm{Y}_{5} \mathrm{Sn}_{3}$ (gray phase); $\mathrm{YCu}_{2}$ (black phase); (d) $4 . \mathrm{Y}_{19} \mathrm{Cu}_{66} \mathrm{Sn}_{15}(673 \mathrm{~K})-\mathrm{Y}_{1.9} \mathrm{Cu}_{9.2} \mathrm{Sn}_{2.8}(\mathrm{gray}$ phase); YCuSn (light gray phase); $\mathrm{YCu}_{5} \mathrm{Sn}$ (dark phase); (e) $4 . \mathrm{Y}_{19} \mathrm{Cu}_{66} \mathrm{Sn}_{15}(773 \mathrm{~K})-\mathrm{Y}_{1.9} \mathrm{Cu}_{9.2} \mathrm{Sn}_{2.8}(\mathrm{gray}$ phase); YCuSn (light gray phase); $\mathrm{YCu}_{5} \mathrm{Sn}$ (dark phase); (f) $15 . \mathrm{Y}_{30} \mathrm{Cu}_{10} \mathrm{Sn}_{60}-\mathrm{Y}_{3} \mathrm{Cu}_{4} \mathrm{Sn}_{4}$ (gray phase); $\mathrm{YSn}_{2}$ (light gray phase); $\mathrm{Y}_{2} \mathrm{Sn}_{5}$ (white phase).

\begin{abstract}
"Y ${ }_{19} \mathrm{Cu}_{66} \mathrm{Sn}_{15}$ "
Previous investigations of the $\mathrm{Cu}$-rich corner of the $R-\mathrm{Cu}-\mathrm{Sn}$ ternary systems, where $R=\mathrm{Y}, \mathrm{La}-\mathrm{Yb}$, have shown the formation of ternary phases at the composition $R_{15} \mathrm{Cu}_{70} \mathrm{Sn}_{15}$, crystallizing with $\mathrm{CeCu}_{6}$ - or $\mathrm{CeCu}_{5} \mathrm{Au}$-type (ordered variant of the former) structure [25,26], and $R_{1.9} \mathrm{Cu}_{9.2} \mathrm{Sn}_{2.8}$ compounds at the composition $\sim R_{14} \mathrm{Cu}_{66} \mathrm{Sn}_{20}(R=\mathrm{Y}, \mathrm{Ce}-\mathrm{Sm}, \mathrm{Gd}-\mathrm{Lu})$, with a hexagonal structure of the $\mathrm{CeNi}_{5} \mathrm{Sn}$ type [7]. $\mathrm{X}$-ray analysis of our samples prepared in the $\mathrm{Cu}$-rich
\end{abstract}

corner of the $\mathrm{Y}-\mathrm{Cu}-\mathrm{Sn}$ system confirmed the formation of both $\mathrm{YCu}_{5} \mathrm{Sn}$ and $\mathrm{Y}_{1.9} \mathrm{Cu}_{9.2} \mathrm{Sn}_{2.8}$. Phase analysis of $\mathrm{Y}_{19} \mathrm{Cu}_{66} \mathrm{Sn}_{15}$ samples annealed at 673 and $773 \mathrm{~K}$ clearly showed the presence of the main phase $\mathrm{Y}_{1.9} \mathrm{Cu}_{9.2} \mathrm{Sn}_{2.8}\left(\mathrm{CeNi}_{5} \mathrm{Sn}\right.$-type structure), in equilibrium with $\mathrm{YCu}_{5} \mathrm{Sn}\left(\mathrm{CeCu}_{6}\right.$-type $)$ and $\mathrm{YCuSn}$ (NdPtSb-type). Taking into account the closeness of the compositions, we may state that the " $\mathrm{Y}_{19} \mathrm{Cu}_{66} \mathrm{Sn}_{15}$ " phase reported in [1] is probably identical to the $\mathrm{YCu}_{5} \mathrm{Sn}$ stannide. 
Table 3 Atomic and isotropic displacement parameters for the $\mathrm{YCu}_{4.65} \mathrm{Sn}_{0.35}$ compound, space group $F-43 m$.

\begin{tabular}{c|c|c|c|c|c}
\hline \multirow{2}{*}{ Atom } & $\begin{array}{c}\text { Wyckoff } \\
\text { position }\end{array}$ & $x$ & $y$ & $z$ & $B_{\text {iso }} \cdot 10^{2}, \mathrm{~nm}^{2}$ \\
\hline $\mathrm{Y}$ & $4 c$ & $1 / 4$ & $1 / 4$ & $1 / 4$ & $0.72(9)$ \\
$\mathrm{Cu}$ & $16 e$ & $0.6252(4)$ & $x$ & $x$ & $0.97(2)$ \\
$M^{\mathrm{a}}$ & $4 a$ & 0 & 0 & 0 & $0.68(9)$ \\
\hline
\end{tabular}

${ }^{\mathrm{a}} M=0.65(1) \mathrm{Cu}+0.35(2) \mathrm{Sn}$.

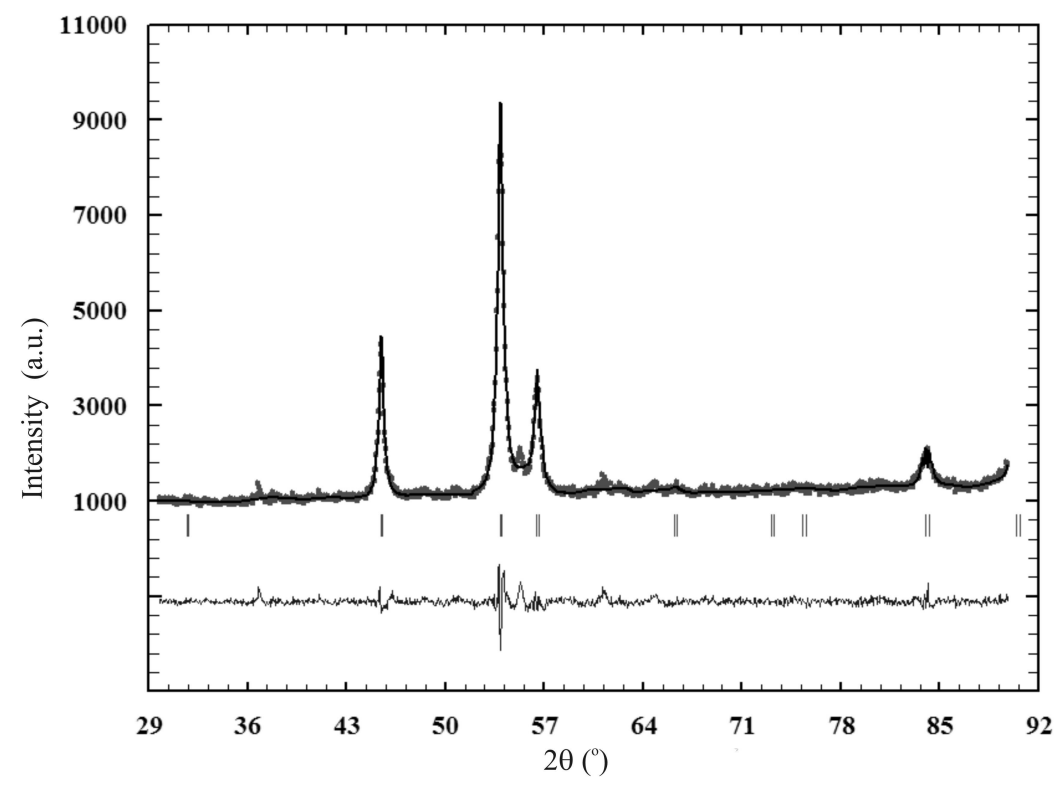

Fig. 3 Observed, calculated and difference X-ray patterns for $\mathrm{YCu}_{4.65} \mathrm{Sn}_{0.35}$.

Crystal structure of the $\mathrm{YCu}_{4.65} \mathrm{Sn}_{0.35}$ compound

From the results of the $\mathrm{X}$-ray analysis of the samples in the $\mathrm{Cu}$-rich part of the $\mathrm{Y}-\mathrm{Cu}-\mathrm{Sn}$ system, a new ternary compound was found at the approximate composition $\mathrm{Y}_{17} \mathrm{Cu}_{78} \mathrm{Sn}_{5}$. The powder pattern of the $\mathrm{Y}_{17} \mathrm{Cu}_{78} \mathrm{Sn}_{5}$ sample was indexed on the basis of a cubic lattice with cell parameter $a=0.7086(1) \mathrm{nm}$, and the compound could be assigned a $\mathrm{MgCu}_{4} \mathrm{Sn}$-type structure (a superstructure of the $\mathrm{AuBe}_{5}$ type, space group $F-43 m)$. The final atomic parameters, refined to $R_{\mathrm{p}}=0.038, R_{\mathrm{wp}}=0.015, R_{\mathrm{Bragg}}=0.026$, are listed in Table 3. The chemical formula according to Rietveld refinement can be expressed as $\mathrm{YCu}_{4.65} \mathrm{Sn}_{0.35}$, which is in a good agreement with the microprobe analysis $\left(\mathrm{Y}_{16.60} \mathrm{Cu}_{79.02} \mathrm{Sn}_{4.38}\right)$. The observed, calculated, and difference X-ray patterns of the $\mathrm{YCu}_{4.65} \mathrm{Sn}_{0.35}$ compound are presented in Fig. 3. Similar cell parameters were refined for multiphase samples, supporting the conclusion that no significant homogeneity range exists at $673 \mathrm{~K}$.

According to literature data [17], the binary phase $\mathrm{YCu}_{5}$ crystallizes with a hexagonal $\mathrm{CaCu}_{5}$-type structure, nevertheless, for some $R-\mathrm{Cu}$ binary systems two structural modifications (hexagonal $\mathrm{CaCu}_{5}$ type, cubic $\mathrm{AuBe}_{5}$ type), are observed for the $R \mathrm{Cu}_{5}$ compounds ( $R=\mathrm{Gd}$, Tb, Dy) [17], depending on the annealing temperature. As mentioned above, under our conditions (annealing at $673 \mathrm{~K}$ ) an $\mathrm{YCu}_{5}$ compound with hexagonal $\mathrm{CaCu}_{5}$-type structure was identified. After replacement of part of the $\mathrm{Cu}$ atoms by $\mathrm{Sn}$ in the ternary region of the $\mathrm{Y}-\mathrm{Cu}-\mathrm{Sn}$ system, the ternary compound $\mathrm{YCu}_{4.65} \mathrm{Sn}_{0.35}$ with cubic $\mathrm{MgCu}_{4} \mathrm{Sn}$-type structure forms. We believe the latter is a true ternary compound, however, it cannot be completely excluded that $\mathrm{YCu}_{4.65} \mathrm{Sn}_{0.35}$ represents an extension of a binary phase, stabilized by small amounts of $\mathrm{Sn}$ at the temperature of the investigation. A similar cubic ternary phase, $\mathrm{YbCu}_{4.4} \mathrm{Sn}_{0.6}$, was observed in the $\mathrm{Yb}-\mathrm{Cu}-\mathrm{Sn}$ system [12].

\section{Final remarks}

Five ternary compounds were found in the isothermal section at $673 \mathrm{~K}$ of the phase diagram of the $\mathrm{Y}-\mathrm{Cu}-\mathrm{Sn}$ system. The existence of the same stannides: YCuSn, $\mathrm{Y}_{3} \mathrm{Cu}_{4} \mathrm{Sn}_{4}, \mathrm{YCu}_{5} \mathrm{Sn}, \mathrm{Y}_{1.9} \mathrm{Cu}_{9.2} \mathrm{Sn}_{2.8}$, and $\mathrm{YCu}_{4.65} \mathrm{Sn}_{0.35}$, was also confirmed at $773 \mathrm{~K}$. Comparing the $\mathrm{Y}-\mathrm{Cu}-\mathrm{Sn}$ system investigated here with previously studied $R-\mathrm{Cu}-\mathrm{Sn}$ systems containing heavy rare earths, one may note the close analogy in stoichiometry and crystal structure of most of the compounds, i.e. $R \mathrm{CuSn}, R_{3} \mathrm{Cu}_{4} \mathrm{Sn}_{4}, R_{1.9} \mathrm{Cu}_{9.2} \mathrm{Sn}_{2.8}$, and $R \mathrm{Cu}_{5} \mathrm{Sn}$ (the latter does not form with $\mathrm{Lu}$ ). A distinct 
feature of the $\mathrm{Y}-\mathrm{Cu}-\mathrm{Sn}$ system is related to the existence of the cubic phase $\mathrm{YCu}_{4.65} \mathrm{Sn}_{0.35}$, an analogue of which has only been observed in the $\mathrm{Yb}-\mathrm{Cu}-\mathrm{Sn}$ system [12].

\section{Acknowledgement}

The work was supported by the Ministry of Ukraine for Education and Science (grant No. 0112U001279) and the grant "Search for new structure types" (MPDS, Switzerland).

\section{References}

[1] Y. Zhuang, C. Qin, J. Li, J. Less-Common Met. 175 (1991) 97-101.

[2] A.E. Dwight, Proc. $12^{\text {th }}$ Rare Earth Res. Conf. 1 (1976) 480-489.

[3] C.P. Sebastian, C. Fehse, H. Eckert, R.D. Hoffman, R. Pöttgen, Solid State Sci. 8 (2006) 1386-1392.

[4] F. Thirion, J. Steinmetz, B. Malaman, Mater. Res. Bull. 18 (1983) 1537-1542.

[5] Ya. Mudryk, O. Isnard, L. Romaka, D. Fruchart, Solid State Commun. 119 (2001) 423-427.

[6] K. Kaczmarska, J. Pierre, A. Slebarski, A. Starczewska, J. Magn. Magn. Mater. 127 (1993) 151-158.

[7] V.V. Romaka, D. Fruchart, R. Gladyshevskii, P. Rogl, N. Koblyuk, J. Alloys Compd. 460 (2008) 283-288.

[8] L. Romaka, V.V. Romaka, E.K. Hlil, D. Fruchart, Chem. Met. Alloys 2 (2009) 68-74.

[9] O.I. Bodak, V.V. Romaka, A.V. Tkachuk, L.P. Romaka, Yu.V. Stadnyk, J. Alloys Compd. 395 (2005) 113-116.

[10] I.V. Senkovska, Ya.S. Mudryk, L.P. Romaka, O.I. Bodak, J. Alloys Compd. 312 (2000) 124-129.

[11] L. Romaka, V.V. Romaka, V. Davydov, Chem. Met. Alloys 1(2) (2008) 192-197.
[12] G. Zanicchi, D. Mazzone, M.L. Fornasini, P. Riani, R. Marazza, R. Ferro, Intermetallics 7 (1999) 957.

[13] V. Romaka, Yu. Gorelenko, L. Romaka, Visn. Lviv. Univ., Ser. Khim. 49 (2008) 3-9.

[14] L.G. Akselrud, Yu.N. Grin, P.Yu. Zavalii, V.K. Pecharsky, V.S. Fundamenskii. CSD Universal Program Package for Single Crystal or Powder Structure Data Treatment, Coll. Abstr. 12 th Eur. Crystallogr. Meet., Nauka, Moscow, 1989, Vol. 3, p. 155.

[15] Rodriguez-Carvajal, J. FULLPROF: A Program for Rietveld Refinement and Pattern Matching Analysis, version 3.5d, Laboratoire Léon Brillouin (CEA-CNRS), Saclay, France, 1998.

[16] A. Palenzona, P. Manfrinetti, J. Alloys Compd. 201 (1993) 43-47.

[17] H. Okamoto (Ed.), Phase Diagrams for Binary Alloys, ASM, Materials Park, Ohio, 2000.

[18] P. Villars, K. Cenzual (Eds.), Pearson's Crystal Data, Crystal Structure Database for Inorganic Compounds, ASM, Materials Park, OH, Release 2013/14.

[19] J.M. Engels, M. Gasgnier, G. Blaise, J. Alloys Compd. 267 (1998) 294-301.

[20] N.M. Bilyavina, M.V. Timoshenko, Yu.O. Titov, V.Ya. Markiv, M.S. Slobodyanik, Ukr. Khim. Zh. 75(10) (2009) 67-71.

[21] Y. Zhang, H. Xie, J. Jiang, Y. Xu, Y. Wang, Y. Zhuang, J. Alloys Compd. 461 (2008) 570-573.

[22] P. Riani, D. Mazzone, G. Zanicchi, R. Marazza, R. Ferro, Intermetallics 5 (1997) 507-514.

[23] P. Riani, D. Mazzone, R. Marazza, G. Zanicchi, R. Ferro, Intermetallics 8 (2000) 259-266.

[24] P. Riani, M.L. Fornasini, R. Marazza, D. Mazzone, G. Zanicchi, R. Ferro, Intermetallics 7 (1999) 835-846.

[25] R.V. Skolozdra, L.P. Romaka, L.G. Akselrud, J. Pierre, J. Alloys Compd. 262-263 (1997) 346-349.

[26] Ya. Mudryk, O. Isnard, L. Romaka, D. Fruchart, Solid State Commun. 119 (2001) 423-427. 